УдК 537.632

\title{
ОСОБЕННОСТИ МОДУЛЯЦИИ ОПТИЧЕСКОГО ИЗЛУЧЕНИЯ ПРИ МАГНИТОМЕХАНИЧЕСКИХ КОЛЕБАНИЯХ В ДВУХСЛОЙНЫХ КОМПОЗИЦИОННЫХ СТРУКТУРАХ
}

\author{
ЛИНЧЕВСКИЙ И. В. \\ Национальный технический университет Украинь \\ «Киевский политехнический институт», \\ Украина, Киев, 03056, пр-т Победы 37
}

\begin{abstract}
Аннотация. Исследованы особенности модуляции оптического излучения при возбуждении магнитомеханических колебаний в композиционной структуре магнитооптический кристалл и магнитопассивный слой. Получены аналитические выражения для амплитудно- и фазочастотных характеристик магнитооптического модулятора света на основе эффекта Фарадея для низкочастотной моды в условиях магнитомеханического резонанса. Приведены результаты теоретических и экспериментальных исследований модулятора в виде двухслойной композиционной структуры из иттриевого феррит граната и кварцевого стекла. Экспериментально получено относительное изменение амплитуды поворота плоскости поляризации в области частот резонанса на уровне $25 \%$ и фазовая задержка $22^{\circ}$
\end{abstract}

Ключевые слова: магнитооптический модулятор, эффект Фарадея, магнитомеханический резонанс

\section{ВВЕДЕНИЕ}

Использование эффекта Фарадея для модуляции света получило широкое распространение в науке и технике. Дополнительные возможности при модуляции света открывает использование для этих целей магнитооптических кристаллов (МОК) при возбуждении в последних магнитомеханических колебаний [1]. При выполнении условий магнитомеханического резонанса высокодобротные механические колебания способны усилить механические напряжения в МОК. Это в свою очередь приводит к дополнительному изменению намагниченности образца вследствие обратного магнитомеханического эффекта. В результате свет, проходящий через магнитооптический кристалл, испытывает резонансные изменения угла поворота плоскости поляризации, как по амплитуде, так и по начальной фазе.

Несмотря на существование МОК с высоким удельным углом поворота плоскости поляризации (2-3 град/мкм для висмут иттриевого граната) для некоторых задач, таких как создание магнитоуправляемого автогенератора на МОК [2], измерение материальных констант кристаллов и др., именно амплитудно- и фазочастотные характеристики магнитооптического модулятора света на основе на эффекта Фарадея в области частот магнитомеханического резонанса являются определяющими.

* Работа выполнена в рамках научно-исследовательской работы г/p № $0113 \mathrm{u} 004190$. 